\title{
Cytokine profiles in highly active antiretroviral treatment non-adherent, adherent and naive HIV-1 infected patients in Western Kenya
}

\author{
Fauzia Musa ${ }^{1}$, Nathan Shaviya ${ }^{2}$, Fidelis Mambo ${ }^{3}$, Collins Abonyo ${ }^{3}$, Erick Barasa ${ }^{3}$, \\ Philemon Wafula ${ }^{4}$, George Sowayi ${ }^{3}$, Mustafa Barasa ${ }^{3}$, Tom Were ${ }^{5}$
}

1. Kakamega Provincial General Hospital.

2.Masinde Muliro University of Science and Technology, Medical Laboratory Sciences.

3. Masinde Muliro University of Science and Technology.

4. Kenya Ministry of Health.

5. Masinde Muliro University of Science and Technology, Biological Sciences.

\begin{abstract}
Background: Cytokines play an important role in signaling the immune system to build an adequate immune response against HIV. HIV distorts the balance between pro and anti-inflammatory cytokines causing viral replication. Highly active antiretroviral treatment (HAART) acts by trying to restore pro and anti-inflammatory cytokine balance. It is not clear how HAART non-adherence influences circulating cytokine levels. This study therefore determined cytokine levels in HAART non-adherent individuals.

Methods: This cross-sectional study recruited 163 participants (51 controls, 23 HIV-1+ HAART naive, 28 HAART-adherent 6 months, 19 HAART-adherent 12 months and 42 HAART non-adherent). Cytokines were analyzed by ELISA while CD4 T cells determined in $3.0 \mu$ l of whole blood using BD FACSCaliburTM and viral load in $0.2 \mathrm{ml}$ plasma sample using Abbott Molecular m2000sp sample preparation and m2000rt real-time amplification and detection systems (Abbott Molecular Inc., Illinois, USA) according to the manufacturer's methods.

Results: IL-4, IL-6, IL-10, TNF- $\alpha$ and TGF- $\beta$ were significantly elevated in HIV-1 HAART non-adherent compared with HIV-1 HAART adherent and healthy controls $\mathrm{P}<0.01$. IFN- $\gamma$ was significantly decreased in HIV-1 HAART non-adherent compared with HIV-1 HAART adherent and healthy controls $\mathrm{P}<0.01$. TNF- $\alpha$ and TGF- $\beta$ were significantly reduced in HIV1 HAART adherent patients at 12 months compared to those at 6 months $\mathrm{P}<0.01$. IL-4 and IL-10 correlated positively with viral load. IL-4, IL-6, IL-10, TNF- $\alpha$ and TGF- $\beta$ associated inversely with CD4 T cell counts and body mass index (BMI).

Conclusion: This study established that HAART adherence is immunologically beneficial to the pro and anti-inflammatory cytokine balance milieu while non-adherence appears to cause alterations in pro and anti-inflammatory cytokines warping the balance in this dichotomy.

Keywords: Cytokines, non-adherence, HAART.

DOI: https:/ / dx.doi.org/10.4314/ahs.v21i4.12

Cite as: Musa F, Shaviya N, Mambo F, Abonyo C, Barasa E, Wafula P, et al. Cytokine profiles in highly active antiretroviral treatment non-adherent, adherent and naive HIV-1 infected patients in Western Kenya. Afri Health Sci. 2021;21(4):1584-92. https://dx.doi. org/10.4314/ahs.v21i4.12
\end{abstract}

\section{Introduction}

Symmetry between cytokine dichotomies is essential for regulation of the immune system ${ }^{1}$. Cells of the immune system secrete pro and anti-inflammatory cytokines during infection which can be assayed in serum and plasma ${ }^{2,3}$. Cytokines present in circulation are pointers

\section{Corresponding author: \\ Nathan Shaviya, \\ Masinde Muliro University of Science \\ and Technology, Medical Laboratory Sciences. \\ Email: shavianathan@gmail.com}

to the magnitude of an immune response. CD4 T cells are the main immune cells that secrete cytokines during HIV infection ${ }^{4}$. These cells are usually activated and differentiate into effector subsets ${ }^{5}$. The classical subsets are primarily T-helper 1 (Th-1) and T-helper 2 (Th-2), but other newer subsets have been identified including follicular helper T-cell (Tfh), T-helper 17 (Th-17) and induced T-regulatory cells (iTreg) 2. Th-1 subset produces vital cytokines such as interferon- $\gamma$ (IFN- $\gamma$ ) and interleukin 2 (IL-2) while Th-2 subset secretes IL-4, IL-5, IL-6 and IL-10 6,7. Previous studies have reported that infection with HIV down-regulates Th-1 and up-regulates Th-2 cytokines creating an imbalance and 
consequently impairing the immune function ${ }^{8,9}$. Therefore, in order to mount an effective cell mediated immune response, a balance between pro-inflammatory cytokines such as IL-2, IL-6, IFN- $\gamma$ and tumor necrosis factor $-\alpha(\mathrm{TNF}-\alpha)$ and anti-inflammatory cytokines like IL-4, IL-5, IL-10 and tumor growth factor- $\beta$ (TGF- $\beta$ ) is necessary.

The world health organization (WHO) recommends immediate enrollment of HIV infected patients on HAART $^{10}$. Use of HAART has apparent benefits to HIV infected individuals like reducing viral load, opportunistic infection, preventing virologic failure and increasing life expectancy ${ }^{11-13}$. Cytokine levels in serum and plasma have been assayed in the context of HAART use. For instance, plasma IL-6 and IL-10 levels have been reported to be decreased in HAART-experienced while IL-4 remained unchanged ${ }^{14-16}$. Additionally, IFN- $\gamma$ levels have been reported to be elevated in HIV patients on HAART ${ }^{16-18}$. Cellular analyses have also revealed increased IL-10 and TGF- $\beta$ specific natural killer $(\mathrm{NK})$ cells in patients on antiretroviral treatment ${ }^{19}$. Consequently, HAART restores the balance between pro- and anti-inflammatory cytokines16. Altogether, these findings imply that antiretroviral treatment modulates circulating cytokines. Nevertheless, there are very few studies that have focused on circulating levels of cytokines in non-adherent HIV patients. Therefore, it is not clear how cytokine levels are affected in HAART non-adherent HIV infected patients.

Although, there is no standard criteria for defining of non-adherence to HAART ${ }^{20,21}$. Some studies have defined HAART non-adherence as less than $95 \%$ of expected monthly drug refills for the duration of antiretroviral use $\mathrm{e}^{22,23}$. Moreover, taking more than 95\% of the prescribed dosage is usually considered optimal while taking less than $95 \%$ of the dosage is subopti$\mathrm{mal}^{24,25}$. The current study adopted the $95 \%$ cut off as the standard for assessing adherence. Furthermore, since cytokines act as surrogate prognostic markers in HIV patients' then quantification of circulating pro and anti-inflammatory cytokines in the context of HAART non-adherence is important for monitoring immune functions.

\section{Materials and methods}

Study design and population. This cross-sectional study was conducted in one hundred and sixty three participants were purposively recruited at the Siaya Coun- ty referral hospital HIV comprehensive care clinic in western Kenya. The study subjects consisted of $51 \mathrm{HIV}$ negative control, $23 \mathrm{HIV}-1$ positive HAART -naive, 28 HIV-1 positive on first line HAART adherent for 6 months, 19 HIV-1 positive on first line HAART adherent for 12 months and 42 HIV-1 positive individuals who were non-adherent to HAART. Since the study area is a malaria and helminthes endemic site, the patients were screened for malaria and helminthes before enrolling. All the HIV-1 positive study participants were on tenofovir disoproxil fumarate (TDF) + lamivudine (3TC) + efavirenz (EFV).

\section{Inclusion and exclusion criteria}

Study subjects were eligible if $\geq 18$ years. Individuals with malaria, helminthes and AIDS like symptoms according to WHO criteria were excluded. In addition, those with a history of diabetes mellitus, opportunistic infections, inflammatory conditions, diarrhoea or pregnancy also were excluded. The control subjects were supposedly healthy HIV negative individuals for both determine and first response kits and were eligible if $\geq 18$ years.

\section{Sample collection}

$3 \mathrm{ml}$ of whole blood were drawn by venipuncture from all participants in the study. The blood samples were aliquoted into EDTA tubes for CD4+ T cell, and viral load and serum separator tubes for cytokines. The sera were separated and stored at $\leq-20^{\circ} \mathrm{C}$ until analyses.

\section{CD4 $\mathrm{T}$ cell enumeration}

CD4+ T cell counts were determined in an automated fashion using the BD FACSCaliburTM flow cytometer (Becton-Dickinson $^{\mathrm{TM}}$, Franklin Lakes, USA). Briefly, $5.0 \mu$ l of EDTA blood samples were placed in a tube and RBC lysis buffer added. After 5 minute incubation, the cells were washed and fluorescent-tagged antibodies (anti-CD3, anti-CD4, and anti-CD45) were added. The cells were incubated for 30 minutes after which the samples were washed and the CD4+ T cells enumerated on the flow cytometer.

\section{HIV-1 viral load}

HIV-1 viral loads were determined using the automated Abbott m2000 System according to the manufacturer's instructions (Abbott Molecular Inc., Illinois, USA). Briefly, RNA was extracted from $0.2 \mathrm{ml}$ serum samples and reverse-transcribed into $\mathrm{cDNA}$. The $\mathrm{cDNA}$ was amplified using HIV-1-specific and internal control 
primers. Fluorescence intensity of the HIV-1 probe was converted into viral loads by the analyzer.

\section{Cytokine measurements.}

Circulating levels of IL-4, IL-6, IL-10, IFN- $\gamma$, TNF- $\alpha$ and TGF- $\beta$ were determined in serum samples using a sandwich enzyme linked immunosorbent assay (ELI$\mathrm{SA}$ ) according to the manufacturer's protocols (R\&D Systems, Inc., Minneapolis, USA).

\section{Data analysis}

Statistical analysis was conducted using IBM ${ }^{\circledR}$ SPSS Statistics 23.0 (SPSS Inc. Chicago, USA). Continuous data (age, and laboratory measures) summarized as medians (IQR) and categorical data presented as proportions were tabulated. Differences in the proportions were determined using the chi-square tests. Statistical comparisons of the continuous data across the study groups were performed using non-parametric ANOVA (Kruskal Wallis) tests followed by Bonferroni's posthoc for multiple comparisons test with a cut off set at $\mathrm{P}<0.01$. Spearman's Rank correlation analyses were used to determine the associations of cytokine levels with viral load, CD4 T cell count and BMI. All tests were two-tailed and $\mathrm{P}<0.05$ was used for statistical inferences.

\section{Ethical consideration}

Ethical approval was obtained from the Masinde Muliro University of Science and Technology Institutional Ethics Review Committee (Protocol: MMU/ COR-403012-V39) and permission conduct the study at the comprehensive care clinic from the Siaya County referral hospital management. Written informed consent was obtained from the study participants prior to enrolment into the study. All HIV-1 infected HAART -naive patients were immediately enrolled on first line treatment of TDF + 3TC + EFV. Information collected as part of this study was kept confidential unless required for patient care, with only access limited to the investigators.

\section{Results}

Demographic and clinical profiles of the study participants. The demographic and clinical characteristics of the study participants are summarized in Table 1. A total 163 adults (males, $\mathrm{n}=73$ and females, $\mathrm{n}=90$ ) were recruited to the study. Age $(\mathrm{P}=0.875)$, gender $(\mathrm{P}=0.109)$ and height $(\mathrm{P}=0.634)$ were similar across the five clinical arms. Body weight $(\mathrm{P}<0.0001)$, BMI $(\mathrm{P}<0.0001)$ and CD4 T cell counts $(\mathrm{P}<0.0001)$ varied across all the study groups. Similarly, viral load $(\mathrm{P}<0.0001)$ was significantly different across four clinical groups since the control arm were HIV negative. Post-hoc analyses using Bonferroni correction were done to reveal between group differences and a cut-off of $\mathrm{P}<0.01$ set. The main outcome group HIV-1 + HAART + non-adherent (median, median, 59.1; IQR, $11.8 \mathrm{~kg}$ ) had significantly lower median body weight than controls (median, 67.8; IQR, $18.0 \mathrm{~kg}$ ) and HIV-1 + HAART + with 12 months use (median, 73.4; IQR, $18.2 \mathrm{~kg}$ ) $\mathrm{P}<0.01$ participants. These analyses revealed no difference in median body weight between HIV-1 + HAART naive and HIV-1 + HAART non-adherent, P>0.01. Additionally, HIV-1 + HAART + non-adherent had lower BMI compared with HIV-1 - HAART- (median, 21.1; IQR $3.7 \mathrm{~kg} / \mathrm{m}^{2}$ vs median, 24.5; IQR $5.3 \mathrm{~kg} / \mathrm{m} 2 ; \mathrm{P}<0.01)$ and HIV-1 + HAART + with 12 months use (median, 21.1; IQR $3.7 \mathrm{~kg} / \mathrm{m}^{2}$ vs median, 25.8; IQR $\left.7.2 \mathrm{~kg} / \mathrm{m}^{2} ; \mathrm{P}<0.01\right)$. HIV-1 + HAART+ non-adherent (median, 423; IQR 252 cells/ $\mu \mathrm{l}$ ) had significantly lower CD4 T cell counts compared with healthy controls (median, 1407; IQR 1303 cells $/ \mu \mathrm{l}), \mathrm{P}>0.01$. 
Table 1: Socio-demographic and clinical characteristics of the study participants

\begin{tabular}{|c|c|c|c|c|c|c|}
\hline Characteristics & HIV- HAART -, n=51 & HIV-1+ HAART-, n=23 & $\begin{array}{l}\text { HIV-1+ HAART+, } \\
6 \text { months use, } n=28\end{array}$ & $\begin{array}{l}\text { HIV-1+ HAART+, } 12 \\
\text { months use, } n=19\end{array}$ & $\begin{array}{l}\text { HIV-1+ } \text { HAART+, } \\
\text { non-adherent, } n=42\end{array}$ & $P$ \\
\hline Age, yrs. & $37.0(6.0)$ & $38.0(7.0)$ & $37.0(6.8)$ & $37.0(8.0)$ & $36.5(9.3)$ & 0.875 \\
\hline $\begin{array}{l}\text { Female/Male, } \\
\text { n }(\%)\end{array}$ & $27 / 24(52.9 / 47.1)$ & 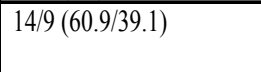 & $20 / 8(71.4 / 28.6)$ & $12 / 7(63.2 / 36.8)$ & $17 / 25(40.5 / 59.5)$ & 0.109 \\
\hline Weight, kg & $67.8(18.0)^{\mathrm{a}}$ & $59.9(11.0)$ & $63.7(12.7)$ & $73.4(18.2)^{\mathrm{a}}$ & $59.1(11.8)$ & $<0.0001$ \\
\hline Height, $m$ & $1.7(0.1)$ & $1.7(0.1)$ & $1.7(0.1)$ & $1.7(0.1)$ & $1.7(0.1)$ & 0.634 \\
\hline BMI, $\mathrm{kg} / \mathrm{m}^{2}$ & $24.5(5.3)^{\mathrm{a}}$ & $20.4(5.1)$ & $23.4(4.1)$ & $25.8(7.2)^{\mathrm{a}}$ & $21.1(3.7)$ & $<0.0001$ \\
\hline $\begin{array}{l}<18.5 \mathrm{~kg} / \mathrm{m}^{2} \\
\mathrm{n}(\%)\end{array}$ & $4(21.1)$ & $3(15.8)$ & $3(15.8)$ & $0(0.0)$ & $9(47.4)$ & - \\
\hline $\begin{array}{l}\geq 18.5 \mathrm{~kg} / \mathrm{m}^{2} \\
\mathrm{n}(\%)\end{array}$ & $47(32.6)$ & $20(13.9)$ & $25(17.4)$ & $19(13.2)$ & $33(22.9)$ & - \\
\hline $\begin{array}{l}\log _{10} \mathrm{HIV}-1 \\
\text { RNA copies } / \mathrm{ml}\end{array}$ & - & $4.5(1.6)$ & $3.1(1.7)$ & $3.6(1.9)$ & $4.6(1.1)$ & $<0.0001$ \\
\hline $\begin{array}{l}<1000 \\
\text { copies } / \mathrm{ml} \mathrm{n}(\%)\end{array}$ & $0(0.0)$ & $4(5.1)$ & $13(16.7)$ & $7(9.0)$ & $3(3.8)$ & - \\
\hline \begin{tabular}{ll|}
$\geq$ & 1000 \\
copies $/ \mathrm{mln}(\%)$
\end{tabular} & $0(0.0)$ & $19(22.4)$ & $15(17.6)$ & $12(14.1)$ & $39(45.9)$ & - \\
\hline $\mathrm{CD} 4+\mathrm{T}$ cells $/ \mu \mathrm{l}$ & $1407(1303)^{\mathrm{a}}$ & $396(349)$ & $577(357)$ & $527(508)$ & $423(252)$ & $<0.0001$ \\
\hline $\begin{array}{l}<500 \text { cells } / \mu \mathrm{l} \\
\mathrm{n}(\%)\end{array}$ & $3(4.5)$ & $16(23.9)$ & $9(13.4)$ & $9(13.4)$ & $30(44.8)$ & - \\
\hline $\begin{array}{l}\geq 500 \text { cells } / \mu \mathrm{l} \\
\mathrm{n}(\%)\end{array}$ & $48(50.0)$ & $7(7.3)$ & $19(19.8)$ & $10(10.4)$ & $12(12.5)$ & - \\
\hline
\end{tabular}

Data are presented as medians (IQR, interquartile range) or as indicated. Data analysis was conducted using Kruskal-Wallis $\mathrm{H}$ test across groups with post-hoc

Bonferroni correction between group comparison set at $P<0.01$ for continuous measures and Chi-Square test for gender distribution. BMI, body mass index.

${ }^{\mathrm{a}} P<0.01$ vs HIV+ HAART + non-adherent. Values in bold are significnt values.

Serum cytokine profiles of study participants. The serum cytokine levels of the study subjects are shown in Table 2. All the six cytokines assayed in the current study showed significant differences in serum levels across the study groups. Similarly, post-hoc analyses using Bonferroni correction were done to establish between group differences and a cut-off of $\mathrm{P}<0.01$ set. IL-4 levels were higher in HIV-1 + HAART + non-adherent (median, 22.1; IQR $8.6 \mathrm{pg} / \mathrm{ml}$ ) compared with HIV-1 - HAART- (median, 3.7; IQR 3.8 pg/ml), HIV$1+$ HAART + with 6 months use (median, 9.5; IQR $4.4 \mathrm{pg} / \mathrm{ml}$ ) and HIV-1 + HAART + with 12 months use (median, 3.2; IQR $2.1 \mathrm{pg} / \mathrm{ml}$ ). Conversely, HIV-1 + HAART + non-adherent had lower IL-4 levels compared with HIV-1+ HAART - naive (median, 29.9; IQR $8.6 \mathrm{pg} / \mathrm{ml}$ ). Similarly, HIV-1 + HAART + non- adherent participants presented with significantly elevated serum IL-6, IL-10 and TNF- $\alpha$ when compared with HIV-1 - HAART-, HIV-1 + HAART + with 6 months use and HIV-1 + HAART + with 12 months use, $\mathrm{P}<0.01$. However, these cytokines were significantly higher in HIV-1 + HAART - naive when compared with HIV-1 + HAART + non-adherent. IFN- $\gamma$ levels were significantly decreased among HIV-1 + HAART + non-adherent compared with HIV-1 - HAART-, HIV-1 + HAART + with 6 months use and HIV-1 + HAART + with 12 months use, $\mathrm{P}<0.01$. IFN- $\gamma$ levels in HIV-1 + HAART- naïve were comparable with HIV-1 + HAART + non-adherent. $<=>$ TGF- $\beta$ were significantly increased in HIV-1 + HAART + non-adherent subjects likened to HIV-1 - HAART- and HIV-1 + HAART + with 12 months use, $\mathrm{P}<0.01$.

Table 2: Serum cytokine levels of the study participants

\begin{tabular}{|c|c|c|c|c|c|c|}
\hline Cytokine, pg/ml & HIV- HAART -, n=51 & HIV+ HAART-, n=23 & $\begin{array}{l}\text { HIV+ HAART+, } 6 \\
\text { months use, } n=28\end{array}$ & $\begin{array}{l}\text { HIV+ HAART+, } 12 \\
\text { months use, } n=19\end{array}$ & $\begin{array}{l}\text { HIV+ HAART+, non- } \\
\text { adherent, } n=42\end{array}$ & $P$ \\
\hline IL-4 & $3.7(3.8)^{\mathrm{a}}$ & $29.9(8.6)^{\mathrm{a}}$ & $9.5(4.4)^{\mathrm{a}}$ & $3.2(2.1)^{\mathrm{a}}$ & $22.1(8.6)$ & $<0.0001$ \\
\hline IL-6 & $4.7(1.1)^{\mathrm{a}}$ & $16.9(5.7)^{\mathrm{a}}$ & $9.8(5.9)^{\mathrm{a}}$ & $8.2(3.5)^{\mathrm{a}}$ & $13.4(7.6)$ & $<0.0001$ \\
\hline IL-10 & $5.4(1.9)^{\mathrm{a}}$ & $32.2(7.2)^{a}$ & $19.5(7.0)^{\mathrm{a}}$ & $7.2(2.2)^{\mathrm{a}}$ & $27.2(9.7)$ & $<0.0001$ \\
\hline IFN- $\gamma$ & $4.9(1.8)^{\mathrm{a}}$ & $0.7(0.1)$ & $2.3(1.0)^{\mathrm{a}}$ & $3.1(0.6)^{\mathrm{a}}$ & $0.9(0.7)$ & $<0.0001$ \\
\hline TNF- $\alpha$ & $9.4(0.8)^{\mathrm{a}}$ & $38.7(17.1)^{\mathrm{a}}$ & $29.9(12.0)$ & $18.6(5.9)^{\mathrm{a}}$ & $29.8(17.7)$ & $<0.0001$ \\
\hline TGF- $\beta$ & $34.4(10.0)^{\mathrm{a}}$ & $89.3(29.1)$ & $77.7(41.4)$ & $64.3(26.3)^{\mathrm{a}}$ & $81.1(35.6)$ & $<0.0001$ \\
\hline
\end{tabular}

Data are presented as medians (IQR, interquartile range). Data analysis was conducted using Kruskal-Wallis $\mathrm{H}$ test across groups with post-hoc Bonferroni correction between group comparison set at $P<0.01$ for continuous measures. ${ }^{a} P<0.01$ vs. HIV+ HAART+ non-adherent. Values in bold are significantalues. 
Association of circulating cytokine levels with HIV clinical markers. Association of cytokine levels with clinical markers is shown in Table 3. IL-4 correlated positively with viral load $(\varrho=0.409 ; \mathrm{P}<0.0001)$ while it correlated inversely with CD4 T cell count $(\varrho=-0.521 ; \mathrm{P}<0.0001)$ and BMI $(\varrho=-0.502 ; \mathrm{P}<0.0001)$. Similarly, IL-10 correlated positively with viral load $(\varrho=0.272 ; \mathrm{P}=0.004)$ and inversely with CD4 T cell count $(\varrho=-0.627 ; \mathrm{P}<0.0001)$ as well as BMI $(\varrho=-0.376 ; \mathrm{P}<0.0001)$. IL- 6 and TNF- $\alpha$ correlated inversely with CD4 T cell count $(\varrho=-0.492$; $\mathrm{P}<0.0001$ and $\varrho=-0.595 ; \mathrm{P}<0.0001)$ and $\mathrm{BMI}(\varrho=$ $-0.308 ; \mathrm{P}<0.0001)$ and $(\varrho=-0.292 ; \mathrm{P}<0.0001)$ respectively. Conversely, IFN- $\gamma$ correlated inversely with viral load $(\varrho=-0.326 ; \mathrm{P}<0.0001)$ and positively with CD4 T cell count $(\varrho=0.619 ; \mathrm{P}<0.0001)$ in addition to BMI $(\varrho=$ $-0.342 ; \mathrm{P}<0.0001)$. TGF- $\beta$ correlated negatively with CD4 T cell counts $(\varrho=-0.526 ; \mathrm{P}<0.0001)$ and BMI $(\varrho=$ $-0.216 ; \mathrm{P}=0.006)$.

Table 3: Association of serum cytokine levels with HIV prognostic markers

\begin{tabular}{|c|c|c|c|c|c|c|}
\hline Cytokine & \multicolumn{2}{|c|}{$\log _{10}$ HIV-1 RNA copies } & \multicolumn{2}{|c|}{ CD4+ T cells } & \multicolumn{2}{|l|}{ BMI } \\
\hline & $\rho$ & $P$ & $\rho$ & $P$ & $\rho$ & $P$ \\
\hline IL-4 & 0.409 & $<0.0001$ & -0.521 & $<0.0001$ & -0.502 & $<0.0001$ \\
\hline$I L-6$ & 0.129 & 0.175 & -0.492 & $<0.0001$ & -0.308 & $<0.0001$ \\
\hline IL-10 & 0.272 & 0.004 & -0.627 & $<0.0001$ & -0.376 & $<0.0001$ \\
\hline$I F N-\gamma$ & -0.326 & $<0.0001$ & 0.619 & $<0.0001$ & 0.342 & $<0.0001$ \\
\hline$T N F-\alpha$ & 0.139 & 0.145 & -0.595 & $<0.0001$ & -0.292 & $<0.0001$ \\
\hline$T G F-\beta$ & -0.081 & 0.395 & -0.526 & $<0.0001$ & -0.216 & 0.006 \\
\hline
\end{tabular}

Data presented are correlation coefficient (rho, $\rho$ ) with associated values. Statistical analysis was performed using Spearman's rank correlation test. IL-4, interleukin-4. IL-6, interleukin-6. IL-10, interleukin-10. IFN- $\gamma$, interferon-gamma. TNF- $\alpha$, tumor necrosis factor- $\alpha$. TGF- $\beta$, tumor growth factor- $\beta$. Values in bold indicate significant $P$ values.

Predictors of HIV disease markers. Regression modelling for cytokines predicting viral load in HIV infected individuals was significant $(F(6,162)=21.216$, $\mathrm{P}<0.0001$ ) with the entire set of cytokines (IL-4, IL-6, IL-10, IFN- $\gamma$, TNF- $\alpha$ and TGF- $\beta$ ) accounting for $42.9 \%$ of the variance in the viral load $(\mathrm{R}=0.671, \mathrm{R} 2=0.429)$ while IFN- $\gamma$ individually influenced viral load by $13.5 \%$, $\mathrm{P}<0.0001$. The other cytokines did not have significant influence on the viral load. Prediction for CD4 T cell counts in HIV infected participants was also significant $(\mathrm{F}(6,162)=21.504, \mathrm{P}<0.0001)$ with all the six cytokine accounting for $41.5 \%$ variation in CD4 $\mathrm{T}$ cell counts $(\mathrm{R}=0.661, \mathrm{R} 2=0.415) . \quad \mathrm{IFN}-\gamma$ affected $\mathrm{CD} 4 \mathrm{~T}$ cell counts significantly by $2.7 \%, \mathrm{P}=0.004$. Overall variance in BMI was significant $(\mathrm{F}(6,162)=8.497, \mathrm{P}<0.0001)$ with the cytokines assayed accounting for $19.3 \%$ of the variance. IL-4 is the only cytokine that had individual significant influence on $\mathrm{BMI}$ by $4.8 \%, \mathrm{P}=0.002$.

\section{Discussion}

The current study assayed pro and anti-inflammatory cytokines in HIV-1 infected patients who were non-adherent to HAART and compared the serum levels with HAART adherent, naive as well as healthy controls. The pro-inflammatory cytokines analyzed included IL6 , IFN- $\gamma$ and TNF- $\alpha$. IL- 6 and TNF- $\alpha$ were elevated in HIV-1 infected individuals and decreased with consistent HAART use. IL- 6 and TNF- $\alpha$ appeared to decrease steadily in patients who were on HAART regularly.
Nevertheless, IL- 6 and TNF- $\alpha$ were found to be elevated in non-adherent patients. On the other hand serum IFN- $\gamma$ levels were decreased in HIV-1 infected patients. Consistent use of HAART seemed to lead to an elevation of serum IFN- $\gamma$. Non-adherence seemed to cause a decrease in serum IFN- $\gamma$ levels. Contrary to these findings, some studies have reported no changes in serum IL-6 levels among HIV patients on HAART ${ }^{26,27}$. While a recent finding showed that IL-6 in HIV patients on HAART were likely to increase when CD4 T cells increased14. Though, several longitudinal reports have revealed concordant findings with the current study of a decrease in IL-6 with adherence to HAART ${ }^{16,28}$. TNF- $\alpha$ has also been found to be elevated in HIV infected HAART naive individuals but serum levels decrease with HAART use ${ }^{29,30}$. Although, it is important to note that different HAART regimens affect TNF- $\alpha$ levels differently ${ }^{31}$. Also, there seems to be no clear pattern on how HAART influences serum IFN- $\gamma$ levels in HIV. Some studies have reported constantly high circulating IFN- $\gamma$ levels even with consistent HAART use $^{18,32}$. Conversely, some studies find IFN- $\gamma$ levels to be decreased in HIV infected individuals on HAART ${ }^{16,33}$. This study reports an elevation in serum IFN- $\gamma$ levels with adherence to HAART. IFN- $\gamma$ is a Th1 cytokine, usually infection with HIV causes a shift from Th1 to Th2 ${ }^{34,35}$. Accordingly, serum IFN- $\gamma$ are expected to be low during infection while HAART use should boost the secretion of IFN- $\gamma$ by immune cells. Overall, these 
pro-inflammatory cytokines play important immune roles during infection with HIV-1. Our findings appear to suggest a reversal on serum cytokine levels following non-adherence. IL- 6 and TNF- $\alpha$ were elevated while IFN- $\gamma$ decreased in individuals who were non-adherent HIV-1 interfering with the effect of HAART on circulating pro-inflammatory cytokines. Furthermore, this study established a positive correlation between IL-4 and viral load. Likewise, IFN- $\gamma$ correlated positively with CD4 T cell counts and BMI. Contrariwise, IL-4, TNF- $\alpha$ and IFN- $\gamma$ associated inversely with CD4 T cell counts and BMI. Similarly other studies have reported elevated IL-4 levels in HIV patients with a high viral load ${ }^{36}$. IFN- $\gamma$ being a Th1 cytokine is definitely down-regulated during HIV-1 infection promoting an environment suitable for viral replication and CD4 $\mathrm{T}$ cell loss ${ }^{37}$. This isconsistent with hierarchical analysis in this study that revealed IFN- $\gamma$ to have an overall influence on viral load and CD4 T cell counts.

IL-4, IL-10 and TGF- $\beta$ were the anti-inflammatory cytokines examined in this study. Infection with HIV seemed to cause an elevation of serum levels of the three cytokines. Adherence to HAART over a long duration appeared to lower anti-inflammatory cytokines in circulation. However, circulating levels of these cytokines in non-adherent HIV patients were found to be raised. Infection with HIV has been shown to lead to a switch from Th1 to Th2 cytokines where IL-4 and IL-10 belong ${ }^{38,39}$. Consequently, these cytokines are expected to be elevated in serum after infection. Since HAART acts to restore cytokine balance, it follows that consistent use should lower serum IL-4 and IL-10 significantly8. However, a recent study comparing serum IL-4 and IL-10 levels in HAART naive and experienced HIV patients found similar IL-4 levels while IL-10 was decreased significantly in HAART experienced individuals ${ }^{40}$. TGF- $\beta$ in cellular immunity has been shown to block Th1/Th2 differentiation and suppresses IL2, IL-4 and IFN- $\gamma$ secretion ${ }^{41,42}$. Elevated serum levels have been consistently seen after infection with HIV indicative of disease progression ${ }^{43}$. Appropriate use of HAART lowers serum TGF- $\beta$ levels significantly improving disease prognosis ${ }^{44}$. In the current study, total adherence to HAART seemed to lower serum levels of the anti-inflammatory cytokines in effect improving disease outcomes in HIV-1 patients. Though, non-adherence appeared to cause an elevation in anti-inflammatory cytokines thus reversing the effects of HAART. Additionally, IL-4 and IL-10 were positively correlated with viral load while IL-4, IL-10 and TGF- $\beta$ were inversely associated with $\mathrm{CD} 4 \mathrm{~T}$ cell counts and BMI. These findings imply adverse effects off non-adherence to HAART since non-adherence caused elevation of anti-inflammatory cytokines. Elevated IL-4 and IL-10 for instance is correlated with high viral load, low CD4 $T$ cells and BMI. In addition, hierarchical prediction showed IL-4 to have an influence on BMI in HIV-1 infected patients in addition to all the cytokines combined. Raised TGF- $\beta$ would result in low CD4 T cells and BMI hence poor prognosis. Studies have shown that HAART causes secretion of IL-2 which restores Th1 cytokine profiles in HIV individuals ${ }^{45}$. Therefore, non-adherence may distort Th1 cytokine restoration causing an imbalance in the pro/anti-inflammatory cytokine milieu.

Overall, this study revealed that non-adherence to HAART results in the elevation of serum IL-4, IL-6, IL-10, TNF- $\alpha$ and TGF- $\beta$ while it decreases IFN- $\gamma$. These findings suggest a reversal of the effects of adherence to HAART and modulation of the Th1/ Th2 cytokine switch. This ultimately leads to adverse effects and poor HIV-1 prognosis. Also, IFN- $\gamma$ I and IL-4 are important predictors of markers ofdisease progression in HIV-1 infected non-adherent individuals.

\section{Conclusion}

This study found out that non-adherence to HAART in HIV-1 infected individuals alters serum levels of pro (TNF- $\alpha$, IL- 6 and IFN- $\gamma$ ) and anti-inflammatory (IL-4, IL-10 and TGF- $\beta$ ) cytokines, distorting the balance in this dichotomy. Additionally, circulating IL-6, TNF- $\alpha$, IFN- $\gamma$, IL-4, IL-10 and TGF- $\beta$ levels can be used as potential surrogate markers of HIV-1 disease progression and antiretroviral use. Likewise, to monitor disease prognosis in HIV-1 infected HAART non-adherent individuals.

\section{Recommendation}

In our view, additional studies with greater number of recruited participants is required to validate the current findings over time.

\section{Declarations}

\section{Acknowledgements.}

We thank the study participants for making this study possible. We are grateful to the management and staff of the Siaya County referral hospital for their support during the study. 


\section{Consent to publish}

Not applicable.

\section{Competing interests}

None of the authors have a commercial relationship or financial conflict of interest as part of this study.

\section{Authors' contributions}

NS and TW conceived and designed the study. FS, CA, EB, FM, GS and PW performed ELISA, CD4 T cell counts and viral load determination experiments. NS, $\mathrm{MB}$ and TW performed statistical analyses and interpretation of data and co-drafted the manuscript. All authors have read and approved the manuscript.

\section{Availability of data and materials}

The data used to support the findings of this study are included within the article.

\section{Funding}

Funding information is not applicable. This study was not funded.

\section{References}

1. Valdivia A, Ly J, Gonzalez L, Hussain P, Saing T, Islamoglu $\mathrm{H}$, et al. Restoring Cytokine Balance in HIV-Positive Individuals with Low CD4 T Cell Counts. AIDS Res Hum Retroviruses. 2017 Sep 1;33(9):905-18.

2. Luckheeram RV, Zhou R, Verma AD, Xia B. CD4+T Cells: Differentiation and Functions [Internet]. Clinical and Developmental Immunology. 2012 [cited 2020 Mar 1]. Available from: https://www.hindawi.com/journals/ jir/2012/925135/

3. Vajpayee M, Negi N, Kurapati S. The enduring tale of $\mathrm{T}$ cells in HIV immunopathogenesis. Indian J Med Res. 2013 Nov;138(5):682-99.

4. Walker B, McMichael A. The T-Cell Response to HIV. Cold Spring Harb Perspect Med [nternet]. 2012 Nov [cited 2020 Mar 2];2(11). Available from: https://www. ncbi.nlm.nih.gov/pmc/articles/PMC3543107/

5. Tubo NJ, Jenkins MK. CD4+ T Cells: Guardians of the Phagosome. Clin Microbiol Rev. 2014 Apr 1;27(2):200-13.

6. Akdis M, Aab A, Altunbulakli C, Azkur K, Costa $\mathrm{RA}$, Crameri R, et al. Interleukins (from IL-1 to IL-38), interferons, transforming growth factor $\beta$, and TNF- $\alpha$ : Receptors, functions, and roles in diseases. J Allergy Clin Immunol. 2016 Oct 1;138(4):984-1010.

7. Furiati SC, Catarino JS, Silva MV, Silva RF, Estevam RB, Teodoro RB, et al. Th1, Th17, and Treg Responses are Differently Modulated by TNF- $\alpha$ Inhibitors and
Methotrexate in Psoriasis Patients. Sci Rep. 2019 May 17;9(1):1-11.

8. Hernández JC, Stevenson M, Latz E, Urcuqui-Inchima S. HIV Type 1 Infection Up-Regulates TLR2 and TLR4 Expression and Function in Vivo and in Vitro. AIDS Res Hum Retroviruses. 2012 Oct;28(10):1313-28.

9. Kedzierska K, Crowe SM. Cytokines and HIV-1: interactions and clinical implications. Antivir Chem Chemother. 2001 May;12(3):133-50.

10. WHO. WHO Updated recommendations on first-line and second-line antiretroviral regimens and post-exposure prophylaxis and recommendations on early infant diagnosis of HIV [Internet]. WHO. World Health Organization; 2018 [cited 2020 Mar 2]. Available from: http://www.who.int/hiv/pub/guidelines/ ARV2018update/en/

11. Kline ER, Sutliff RL. The Roles of HIV-1 Proteins and Antiretroviral Drug Therapy in HIV-1-Associated Endothelial Dysfunction. J Investig Med Off Publ Am Fed Clin Res. 2008 Jun;56(5):752-69.

12. Mayer KH, Venkatesh KK. Antiretroviral Therapy as HIV Prevention: Status and Prospects. Am J Public Health. 2010 Oct;100(10):1867-76.

13. Ramana KV. Effect of Highly Active Antiretroviral Therapy (HAART) on Human Immunodeficiency Virus Disease Pathogenesis and Progression. Am I Public Health Res. 2014 Jan 23;2(3):68-74.

14. Akase I, Obiako R, Musa B, Opawoye A, Aknamu A. Levels of interleukin 6 and 10 and their relationship to hematological changes in HIV treatment-naïve and treatment-experienced patients [Internet]. 2019 [cited 2020 Mar 3]. Available from: http://www.ssajm.org/ article. asp? issn $=2384-5147$; year $=2019$; volume $=6$; is sue $=2 ;$ spage $=90 ;$ epage $=95$; aulast $=$ Akase

15. Gori E, Mduluza T, Nyagura M, Stray-Pedersen B, Gomo ZA. Inflammation-modulating cytokine profile and lipid interaction in HIV-related risk factors for cardiovascular diseases. Ther Clin Risk Manag. 2016 Nov 11;12:1659-66.

16. Osuji FN, Onyenekwe CC, Ahaneku JE, Ukibe NR. The effects of highly active antiretroviral therapy on the serum levels of pro-inflammatory and anti-inflammatory cytokines in HIV infected subjects. J Biomed Sci [Internet]. 2018 Dec 3 [cited 2019 Jun 26];25. Available from: https://www.ncbi.nlm.nih.gov/pmc/articles/ PMC6276218/

17. Watanabe D, Uehira T, Yonemoto $H$, Bando $H$, Ogawa Y, Yajima K, et al. Sustained High Levels of Serum Interferon- $\gamma$ During HIV-1 Infection: A Specific Trend Different from Other Cytokines. Viral Immunol. 2010 Dec 1;23(6):619-25. 
18. Watanabe D, Uehira T, Suzuki S, Matsumoto E, Ueji T, Hirota K, et al. Clinical characteristics of HIV-1-infected patients with high levels of plasma interferon- $\gamma$ : a multicenter observational study. BMC Infect Dis. 2019 Jan 5;19(1):11.

19. Jiang $Y$, Yang $M$, Sun $X$, Chen $X$, Ma M, Yin X, et al. IL-10+ NK and TGF- $\beta+$ NK cells play negative regulatory roles in HIV infection. BMC Infect Dis [nternet]. 2018 Feb 13 [cited 2020 Mar 3];18. Available from: https://www.ncbi.nlm.nih.gov/pmc/articles/ PMC5812185/

20. Chalker J, Wagner A, Tomson G, Laing R, Johnson $\mathrm{K}$, Wahlström R, et al. Urgent Need for Coordination in Adopting Standardized Antiretroviral Adherence Performance Indicators. JAIDS J Acquir Immune Defic Syndr. 2010 Feb;53(2):159-161.

21. Nachega JB, Stein DM, Lehman DA, Hlatshwayo $\mathrm{D}$, Mothopeng R, Chaisson R e., et al. Adherence to Antiretroviral Therapy in HIV-Infected Adults in Soweto, South Africa. AIDS Res Hum Retroviruses. 2004 Oct 1;20(10):1053-6.

22. Jima F, Tatiparthi R. Prevalence of nonadherence and its associated factors affecting on HIV adults follow-up at antiretroviral therapy clinic in Batu Hospital, Eastern Ethiopia. Indian J Sex Transm Dis AIDS. 2018;39(2):91-7.

23. Semvua SK, Orrell C, Mmbaga BT, Semvua HH, Bartlett JA, Boulle AA. Predictors of non-adherence to antiretroviral therapy among HIV infected patients in northern Tanzania. PLoS One. 2017 Dec 18;12(12):e0189460.

24. Ingersoll KS, Cohen J. The impact of medication regimen factors on adherence to chronic treatment: a review of literature. J Behav Med. 2008 Jun;31(3):213-24. 25. Martin S, Elliott-DeSorbo DK, Calabrese S, Wolters PL, Roby G, Brennan T, et al. A comparison of adherence assessment methods utilized in the United States: perspectives of researchers, HIV-infected children, and their caregivers. AIDS Patient Care STDs. 2009 Aug;23(8):593-601.

26. Burger R. Impact of Interleukin-6 in Hematological Malignancies. Transfus Med Hemotherapy. 2013 Oct;40(5):336-43.

27. Regidor DL, Detels R, Breen EC, Widney DP, Jacobson LP, Palella F, et al. Effect of highly active antiretroviral therapy on biomarkers of B-lymphocyte activation and inflammation. AIDS Lond Engl. 2011 Jan 28;25(3):303-14.

28. Haissman JM, Vestergaard LS, Sembuche S, Erikstrup C, Mmbando B, Mtullu S, et al. Plasma cytokine levels in Tanzanian HIV-1-infected adults and the effect of antiretroviral treatment. J Acquir Immune Defic Syndr 1999. 2009 Dec 1;52(4):493-7.

29. Maharaj NR, Phulukdaree A, Nagiah S, Ramkaran P, Tiloke C, Chuturgoon AA. Pro-Inflammatory Cytokine Levels in HIV Infected and Uninfected Pregnant Women with and without Preeclampsia. PLoS One [Internet]. 2017 Jan 17 [cited 2020 Mar 17];12(1). Available from: https://www.ncbi.nlm.nih.gov/pmc/articles/ PMC5240954/

30. Sm K, Et G, M N, M Y, K A, H C, et al. The effect of HIV infection and HAART on inflammatory biomarkers in a population-based cohort of women. Aids Lond Engl. 2011 Sep 1;25(15):1823-32.

31. Espíndola MS, Lima LJG, Soares LS, Cacemiro MC, Zambuzi FA, Gomes M de S, et al. Dysregulated Immune Activation in Second-Line HAART HIV+ Patients Is Similar to That of Untreated Patients. PLoS One. 2015 Dec 18;10(12):e0145261.

32. Roff SR, Song EN, Yamamoto JK. The Significance of Interferon- $\gamma$ in HIV-1 Pathogenesis, Therapy, and Prophylaxis. Front Immunol [Internet]. 2014 [cited 2020 Mar 17];4. Available from: https://www.frontiersin.org/articles/10.3389/fimmu.2013.00498/full

33. BRAZILLE P, DEREUDDRE-BOSQUET $\mathrm{N}$, LEPORT C, CLAYETTE P, BOYER O, VILDÉ J-L, et al. Decreases in plasma TNF- $\alpha$ level and IFN- $\gamma$ mRNA level in peripheral blood mononuclear cells (PBMC) and an increase in IL-2 mRNA level in PBMC are associated with effective highly active antiretroviral therapy in HIV-infected patients. Clin Exp Immunol. 2003 Feb;131(2):304-11.

34. Douglas SD, Durako S, Sullivan KE, Camarca M, Moscicki A-B, Wilson CM. TH1 and TH2 Cytokine mRNA and Protein Levels in Human Immunodeficiency Virus (HIV)-Seropositive and HIV-Seronegative Youths. Clin Diagn Lab Immunol. 2003 May 1;10(3):399_ 404.

35. Kang W, Li Y, Zhuang Y, Zhao K, Huang D, Sun Y. Dynamic analysis of Th1/Th2 cytokine concentration during antiretroviral therapy of HIV-1/HCV co-infected Patients. BMC Infect Dis. 2012 Apr 25;12(1):102.

36. Wójtowicz A, Bibert S, Taffé P, Bernasconi E, Furrer H, Günthard HF, et al. IL-4 polymorphism influences susceptibility to Pneumocystis jirovecii pneumonia in HIV-positive patients. AIDS. 2019 Sep 1;33(11):17191727.

37. Soper A, Kimura I, Nagaoka S, Konno Y, Yamamoto K, Koyanagi Y, et al. Type I Interferon Responses by HIV-1 Infection: Association with Disease Progression 
and Control. Front Immunol [nternet]. 2018 Jan 15 [cited 2020 Mar 17];8. Available from: https://www.ncbi.nlm. nih.gov/pmc/articles/PMC5775519/

38. Freeman ML, Shive CL, Nguyen TP, Younes S-A, Panigrahi S, Lederman MM. Cytokines and T-Cell Homeostasis in HIV Infection. J Infect Dis. 2016 Oct 1;214(suppl_2):S51-7.

39. Kahle EM, Bolton M, Hughes JP, Donnell D, Celum

C, Lingappa JR, et al. Plasma Cytokine Levels and Risk of HIV Type 1 (HIV-1) Transmission and Acquisition: A Nested Case-Control Study Among HIV-1-Serodiscordant Couples. J Infect Dis. 2015 May 1;211(9):145160 .

40. Bipath P, Levay P, Olorunju S, Viljoen M. A non-specific biomarker of disease activity in HIV/AIDS patients from resource-limited environments. Afr Health Sci. 2015 Jun;15(2):334-43.

41. Gorelik L, Constant S, Flavell RA. Mechanism of Transforming Growth Factor $\beta$-induced Inhibition of T Helper Type 1 Differentiation. J Exp Med. 2002 Jun 3;195(11):1499-505.
42. Yoshimura A, Wakabayashi Y, Mori T. Cellular and molecular basis for the regulation of inflammation by TGF-ß.J Biochem (Tokyo). 2010 Jun;147(6):781-92.

43. Wiercińska-Drapalo A, Flisiak R, Jaroszewicz J, Prokopowicz D. Increased plasma transforming growth factor-beta1 is associated with disease progression in HIV-1-infected patients. Viral Immunol. 2004;17(1):109_ 13.

44. Theron AJ, Anderson R, Rossouw TM, Steel HC. The Role of Transforming Growth Factor Beta-1 in the Progression of HIV/AIDS and Development of Non-AIDS-Defining Fibrotic Disorders. Front Immunol [Internet]. 2017 Nov 2 [cited 2020 Mar 17];8. Available from: https://www.ncbi.nlm.nih.gov/pmc/ articles/PMC5673850/

45. Meira DA, Almeida R, Barbosa AN, de Souza LR, Olivo TET, Henriques RMS, et al. Assessment of cytokine values in serum by RT-PCR in HIV-1 infected individuals with and without highly active anti-retroviral therapy (HAART). J Venom Anim Toxins Trop Dis. 2008;14(4):685-702. 